\title{
Language: Representation of Mind
}

\author{
Muji \\ \{mujifkipunej@gmail.com\} \\ Universitas Jember, Indonesia
}

\begin{abstract}
Language is an effective medium for expressing feelings, ideas, or heart's content as needed. Nowadays, language actors, both speakers and speech partners, replied to each other with expressions that were considered to be detrimental to certain parties, especially those who were not in line with them, both in terms of opinion and interest. This can be easily found in public statements conveyed in print, electronic, and social media, especially statements criticizing or defending the government. Speech that was disgraceful in content and intent can foster prolonged symbolic violence.
\end{abstract}

Keywords: language, representation of mind.

\section{Bahasa: Representasi Pikiran}

\begin{abstract}
Abstrak. Bahasa merupakan media efektif untuk mengungkapkan perasaan, gagasan, atau isi hati sesuai kebutuhan. Dewasa ini, para pelaku berbahasa, baik penutur maupun mitra tutur, saling berbalas ujaran dengan ekspresi-ekspresi yang dinilai dapat merugikan pihak tertentu, khususnya pihak-pihak yang tidak sejalan dengannya, baik dari segi pendapat maupun kepentingan. Hal ini dapat dengan mudah dijumpai pada pernyataanpernyataan publik yang disampaikan di media cetak, elektronik, maupun media sosial, khususnya pernyataan-pernyataan yang bernada mengkritik maupun membela pemerintah. Ujaran yang isi dan maksudnya tercela dapat menumbuhkembangkan kekerasan simbolis yang berkepanjangan.
\end{abstract}

Kata kunci: bahasa, representasi pikiran.

\section{Pendahuluan}

Sering kali ditemukan penutur bahasa Indonesia menggunakan bahasa untuk kepentingan yang tidak seharusnya. Kepentingan yang dimaksud ini seperti menyakiti mitra yang dinilai berseberangan dengan pendapatnya. Persoalan ini penting untuk dibahas, sebab dapat menimbulkan kekerasan (simbolis dan fisik), perpecahan, dan ketidakdamaian hidup bermasyarakat, terlebih di tengah keragaman suku, agama, budaya, bahasa, dan ras. Dewasa ini, penutur bahasa melisankan, menulis, menggambar, berperilaku, dan membuat simbol-simbol secara bebas. Hal itu dimungkinkan karena di era pasca-Reformasi ini siapa pun memiliki hak untuk berpendapat dan bersuara. Sekalipun demikian, pendapat yang mengandung maksud menyakiti, memfitnah, atau menjelek-jelekkan perlu untuk dikendalikan [1]. 
Dewasa ini, penggunaan bahasa yang tidak terpuji dalam wujud lisan, tulisan, gambar, dan gerakan (gesture) sering muncul di media cetak, elektronik, dan media sosial. Tidak maju atau tidak berhasilnya program pembangunan nasional, salah satunya disebabkan oleh pemakaian bahasa yang tidak baik, tidak benar, tidak wajar, dan tidak dapat diterima akal sehat. Terlebih jika penuturan bahasa tersebut disertai silat lidah yang dapat mengalihkan perasaan dan pikiran audiens.

Situasi kekinian di atas merupakan konteks yang melatarblekangi penelitian ini. Penelitian ini bertujuan untuk; (i) mengenal wujud pemakaian bahasa yang tidak baik, tidak benar, tidak wajar, dan tidak dapat diterima akal sehat, (ii) menemukan implikatur wujud pemakaian bahasa yang tidak baik, tidak benar, tidak wajar, dan tidak dapat diterima akal sehat, dan (iii) menemukan modus pemakaian bahasa yang tidak baik, tidak benar, tidak wajar, dan tidak dapat diterima akal sehat [2].

\section{Metode}

Suatu penelitian dapat dinilai berkualitas dan dapat dipertanggungjawabkan isinya, jika dilakukan dengan metode dan langkah-langkah yang runtut. Berikut dijelaskan metode dan langkah yang peneliti gunakan dalam penelitian ini. Peneliti menggunakan desain penelitian kualitatif dengan jenis penelitian fenomenologis. Data yang didapatkan akan dianalisis dan disampaikan apa adanya. Tetapi, tidak semua fenomena bahasa yang ada di media yang diolah. Peneliti hanya akan menganalisis tuturan bahasa yang terindikasi memiliki masalah "mengganggu mitra komunikasi." [3].

Data yang digunakan dalam penelitian ini berupa ujaran, baik lisan, tulisan, gambar/foto, dan suara/bunyi yang terindikasi mengganggu atau tercela. Sumber data didapat dari media sosial yang dimuat pada mesin pencari Google. Teknik pengumpulan data yang dipilih adalah observasi (mengamati ujaran tertentu yang dinilai bermasalah), wawancara (melakukan tanya jawab dengan pakar bahasa dan teman sejawat untuk menentukan apakah data yang dipilih dapat diindikasikan sebagai ujaran yang bermasalah ataukah tidak), dan diskusi kelompok terfokus (focus group discussion) [4].

Menganalisis ujaran yang terindikasi bermasalah bukanlah perkara mudah, karena tidak ada rumus baku untuk mengukur kebenaran dan ketepatan isi serta maksud ujaran. Untuk menemukan kebenaran dan ketepatan isi serta maksudnya, suatu ujaran harus selalu dikaitkan dengan konteks kejadian. Hal ini dikarenakan suatu ujaran tertentu dapat bersifat multitafsir; ketika diduga isi dan maksudnya $\mathrm{X}$, ternyata malah dapat merujuk kepada $\mathrm{P}, \mathrm{Q}, \mathrm{R}$, atau $\mathrm{S}$. Terkait konteks ini, teknik analisis data yang dipilih adalah analisis wacana kritis.

\section{Hasil dan Pembahasan}

Akhir-akhir ini, di ruang publik kita, kerap beredar ujaran yang menurut penuturnya tidak menyinggung atau mengganggu mitra tutur, namun kenyataannya, banyak mitra tutur yang sangat terganggu dan kecewa dengan ujaran-ujaran tersebut. Salah satu contohnya adalah "Semoga Sumatera Barat menjadi provinsi yang memang mendukung negara Pancasila." Pernyataan tersebut disampaikan oleh Puan Maharani dan terbukti menuai kontroversi. Upaya untuk menetralkan ujaran ini agar tidak menimbulkan masalah yang berkepanjangan bukanlah 
perkara mudah. Lebih-lebih jika kebanyakan mitra tutur meyakini ujaran ini menyinggung perasaan.

Kita dapat membandingkan ujaran di atas dengan ujaran yang dinyatakan oleh Ketua Umum PDIP, Megawati Soekarnoputri, ketika ia bertanya-tanya mengapa partainya sulit memenangkan pemilu di Sumatera Barat, meskipun sudah memiliki kantor DPC dan DPD di Bumi Minangkabau tersebut. Ujaran tersebut berbunyi, "Saya pikir kenapa ya, rakyat di Sumbar itu sepertinya belum menyukai PDI Perjuangan?" Pernyataan tersebut disampaikan dalam pengumuman calon kepala daerah-wakil kepala daerah dari PDIP pada Rabu, 2 September 2020. Megawati mengatakan jika melihat dari sejarah bangsa, banyak tokoh asal Sumatera Barat yang menjadi nasionalis. Ia mencontohkan Bung Hatta yang bersama ayahnya, Bung Karno, menjadi proklamator kemerdekaan Indonesia. Ia melanjutkan pernyataan dengan mengatakan, "Padahal kalau kita ingat sejarah bangsa, banyak sekali lho orang dari kalangan Sumatera Barat itu yang menjadi nasionalis.” Megawati pun mengajak para kadernya untuk mempelajari mengapa masih ada daerah yang belum terbuka dengan PDIP [5].

Ilham Azre, peneliti Spektrum Politika, membantah Sumatera Barat dianggap tidak nasionalis atau tidak mendukung Pancasila karena tidak memilih PDIP. Menurutnya, sejak era Reformasi, justru partai-partai nasionalis yang memenangkan pemilu legislatif di Sumatera Barat. Hanya Pemilu 1999 yang dimenangkan partai yang dekat dengan pemilih Islam, yakni Partai Amanat Nasional (PAN). Setelah itu, pemilihan legislatif di Sumbar dimenangi oleh Golkar (2004), Demokrat (2009), Golkar (2014), dan Gerindra (2019).

Ilham Azre melanjutkan bahwa Partai Keadilan Sejahtera (PKS) bahkan tidak pernah memenangkan pemilihan legislatif, meskipun menang dalam pemilihan kepala daerah di Sumbar. Ia kemudian menjelaskan keadaan masyarakat Sumatera Barat dengan menyatakan, "Jadi, masyarakatnya sebenarnya sangat cair." Menurutnya, sebab kekalahan Presiden Joko Widodo dalam dua kali pemilihan presiden di Sumatera Barat adalah faktor ketokohan Prabowo Subianto yang sangat kuat di sana, sedangkan figur Joko Widodo kurang mengena di hati masyarakat [6].

Sebenarnya, ujaran Megawati dan Puan memiliki maksud yang serupa, yaitu terkait keingintahuan mengapa warga Sumbar tidak menyukai PDIP. Perbedaannya, Puan mengungkapkan maksud ujaran dengan terang-terangan, sedangkan Megawati membungkusnya dengan kemasan kesantunan nasional. Jadi, meskipun ujaran yang disampaikan menyentuh perasaan, mitra tutur tidak terlalu merasa sakit hati.

Adapun ujaran yang disampaikan oleh Ilham Azre, sebagai sebuah bantahan terhadap pernyataan Megawati dan Puan, dinilai salah bantah. Maksud ujaran keduanya adalah untuk mempertanyakan alasan warga Sumatera Barat tidak menyukai PDIP, bukan mempertanyakan sifat nasionalis warga Sumatera Barat. Untuk permasalahan nasionalisme, Megawati sudah menyatakan bahwa Sumatera Barat memiliki banyak tokoh nasionalis, seperti Bung Hatta. Pernyataan Ilham yang dikemukakan sebagai bantahan tersebut terindikasi mengipasi rasa sakit warga Sumatera Barat. Pernyataan tersebut tidak muncul sebagai peredam, namun justru mempertajam masalah yang ada.

Seyogianya, perlu dipahami inti masalah yang dipersoalkan. Jika masalah yang dipersoalkan terkait pertanyaan, "Mengapa warga Sumbar tidak menyukai PDIP?" Maka, mencarikan jawaban yang tepat adalah jalan terbaik, bukan memunculkan permasalahan baru yang membuat masalah semakin pelik. Oleh karena itu, sedapatnya memberikan keterangan yang jelas, tegas, dan dapat diterima akal sehat sebagai tanggapan.

Setiap ujaran yang disampaikan di muka umum bisa berdampak besar, baik negatif maupun positif. Maka, semua pihak (penutur dan mitra tutur) diharapkan untuk berhati-hati 
dalam mengekspresikan perilaku berbahasa (lisan, tulisan, gambar/foto, gerak, suara/bunyi, dan sinar/cahaya) di depan umum. Contoh lain dari wujud pemakaian bahasa yang tidak baik, tidak benar, tidak wajar, dan tidak dapat diterima akal sehat dapat dilihat dari pernyataan berikut:

"Saya berasal dari keluarga Masyumi, nenek saya ditangkap Bung Karno karena PRRI. Tapi justru saya direkrut oleh Pak Taufiq, diberi ruang dan kesempatan untuk berekspresi di partai, hingga pada akhirnya diberi kesempatan untuk menjadi calon anggota legislatif dan pada akhirnya menjadi anggota DPR terpilih, sesuatu hal yang tidak mungkin rasanya kalau pakai hitungan kalkulator biasa." [5]

Pernyataan di atas disampaikan oleh Arteria, seorang anggota DPR yang berasal dari keluarga Masyumi. Melihat sejarah masa lalu dirinya, ada pikiran bahwa Arteria pasti tidak dapat menjadi anggota DPR, karena berasal dari keluarga Masyumi dan neneknya ditangkap Bung Karno. Pernyataan tersebut mengesankan bahwa Arteria menyikapi sejarah riwayat hidup keluarganya dengan tidak baik, tidak benar, tidak wajar, dan tidak dapat diterima akal sehat, sebab beranggapan bahwa riwayat tersebut akan membuatnya tidak dapat menjadi anggota dewan. Faktanya, ia tidak menyangka sekarang dapat menjadi anggota DPR. Oleh karena itu, ujaran ini dapat dinilai negatif oleh kebanyakan orang. Kasus seperti ini banyak terjadi dalam beberapa waktu ke belakang, khususnya di media-media daring.

Kebanyakan orang yang cerdas sudah mengetahui dan mengerti mengapa pemakaian bahasa yang tidak baik, tidak benar, tidak wajar, dan tidak dapat diterima akal sehat dipakai penutur bahasa tertentu. Mereka mempunyai niat dan hajat ingin meraih sesuatu yang dibutuhkan oleh dirinya sendiri dan kelompoknya. Tetapi, sayang niat dan hajat tersebut dicapai tidak lewat kelaziman dan adab. Mereka justru mengekspresikan niat dan hajatnya dengan cara-cara yang menyakiti dan menggunakan kata-kata yang kurang patut. Beberapa contoh lain dapat dilihat pada dua kasus berikut:

"Dalam video berdurasi 02.33 menit yang viral, kelompok pendemo berteriak 'bakar PKI' dengan membakar bendera PDI-P adalah tindakan fitnah yang teramat keji dan wajib diproses hukum," kata Rio melalui keterangan tertulis, Kamis (25/6/2020) [5].

Cuplikan di atas diambil dari artikel berjudul "Ketua DPC: Pembakaran Bendera PDI-P Diiringi Teriakan PKI adalah Fitnah," yang ditulis oleh Rakhmat Nur Hakim dan dipublikasikan dalam Kompas.com.

"Kepolisian mendapatkan informasi terkait beredarnya konten penghinaan terhadap Presiden dan berita-berita bohong," tutur Dedi dalam keterangannya, Kamis (9/10/2019). "Seperti berita yang menuduh bahwa Jokowi adalah PKI, dan berita bohong tentang matinya saksi Prabowo-Sandi karena dibacok di PPK Amalatu. Konten-konten tersebut tersangka unggah sendiri pada halaman akun media sosial Facebook dan Instagram miliknya," lanjutnya [7]

Pemakaian bahasa yang tidak terukur dan tidak santun di ruang publik, terlebih menyoal isu-isu sosial politik dewasa ini, kerap mengatasnamakan hak bersuara dan berpendapat. Setiap bentuk pembatasan kerap dinilai tidak sesuai dengan nilai-nilai demokrasi. Akibatnya, ujaran yang berpotensi mengganggu mitra bicara pun dinilai biasa-biasa saja 


\section{Simpulan}

Wujud pemakaian bahasa yang tidak baik, tidak benar, tidak wajar, dan tidak dapat diterima akal sehat ditemukan pada ujaran yang menurut penuturnya dinilai tidak menyinggung atau mengganggu mitra tutur, namun kenyataannya justru sebaliknya. Implikatur pemakaian bahasa yang tidak baik, tidak benar, tidak wajar, dan tidak dapat diterima akal sehat ditemukan pada ujaran yang berupa tuduhan negatif. Terkait temuan penelitian, baik penutur bahasa maupun mitra tutur, seyogianya menjunjung adab, kesantunan, dan itikad baik dalam mengeluarkan pernyataan-pernyataan atau ujaran-ujaran di ranah publik. Perlu diingat bahwa bahasa yang diekspresikan sesungguhnya adalah representasi perilaku penutur bahasa itu sendiri, bukan pihak lain.

\section{Referensi}

[1] Yuliani PA. Jokowi Peringatkan Lawan Politik. 2018, April 10. Diakses dari https://mediaindonesia.com/read/detail/154232-jokowi-peringatkan-lawan-politik

[2] Muji, M. (2020). Bahasa Tayangan Bayang-Bayang Perilaku Misterius. FKIP ePROCEEDING, 75-94.

[3] Saryono. Penelitian Kualitatif. https://pakdosen.co.id/penelitian-kualitatif/ [diakses 10 Februari 2020]; 2019.

[4] Widodo. Teknik Analisis Data dalam Penelitian. http://widodoiain.blogspot.com/2015/02/teknik-analisis-data-dalam-penelitian.html [Diakses 10 Februari 2020]; 2015.

[5] Hakim NR. Ketua DPC: Pembakaran Bendera PDI-P Diiringi Teriakan PKI adalah Fitnah https://nasional.kompas.com/read/2020/06/25/17114081/ketua-dpc-pembakaran bendera-pdi-p-diiringi-teriakan-pki-adalah-fitnah [diakses 7 September 2020]; 2020.

[6] Kampai J. Kecewa ke Puan, Mulyadi-Ali Mukhni Kembalikan Dukungan PDIP di Pilgub Sumbar https://news.detik.com/berita/d-5160714/kecewa-ke-puan-mulyadi-ali-mukhn ikembalikan-dukungan-pdip-di-pilgub-sumbar [diakses 6 September 2020]; 2020.

[7] Putra NP. Polisi Tangkap Pemilik Akun Facebook Penuduh Jokowi. https://www.liputan6.com/news/read/3961191/polisi-tangkap-pemilik-akun-facebookpenuduh-jokowi-pki [diakses 7 September 2020]; 2019. 